\title{
運転条件による燃料のノック性の変動に関する研究 $(2)$
}

\section{出力と燃料のノック性に及ぼす点火時期の影響*}

\author{
山崎毅六** 森 利 淳*** 前田耕**** 高取武夫***
}

The Effects of Operating Conditions of the Engine on Antiknock

Properties of Gasolines (2) The Effects of Spark Advance on Power and Antiknock Properties of Fuels*

by Kiroku Yamazaki**, Toshiatsu Mori***, Tsutomu Maeda**** and Takeo Takatori***

Summary : (1) The relationships between spark advance and power of the CFR engine under various conditions were studied. The maximum power spark advances at engine speed of $600 \mathrm{rpm}$ and 900 rpm were compared with those specified for octane rating by Research and Motor method.

(2) The comparison is made between the knock limited compression ratios by incipient knock and standard knock intensity of Research and Motor method. The possibility of estimating the Research octane number from the incipient knock limited compression ratio is deduced.

(3) It is shown that spark advance and mixture ratio have more effects on antiknock properties as higher octane number fuels are used.

\section{1 はしがき}

一般に点火時期は燃料のノック性わよび出力に大きな影郘を 及ぼすために，ノック性と点火時期との関係を論議する場合に は必ず出力についても考虑されなければならない。走行オクタ ン価の測定において点火時期が重要な役割を演し，あるいは同 一エンシンの要求オクタン価が点火時期により著しく変ること もその1つの現われである。

そこて CFR エンジンの運転諸条件について最高出力を示す 点火時期を求め, 実臨室ノック性測定に現在広く用いられてい る標準運転条件によるものと比較し,さらにノック限界圧縮比 とオクタン価の関保を検討した。

実験したエンシンの運転条件は回転数 600,900 および 1,200 $\mathrm{rpm}$, 圧縮比 4 8, 混合比 12 17, 点火時期 10 35 BTDC, 混合気温度 50 および $150^{\circ} \mathrm{C}$, 冷却液温度 $100^{\circ} \mathrm{C}$, 潤滑油温度 $57 \pm 5^{\circ} \mathrm{C}$ である。财入空気温度および湿度は調節しなかった。 実験時における湿度は空気 $1 \mathrm{~g}$ あたり水 14〜19 mgであった。 出力は直流電気動力計で測定し, 軸馬力と摩擦馬力の和を指示 馬力として計算によって指示平均有效圧を求めた。

\section{CFR エンジンの最高出力点火時期}

\section{1 湿合比と最高出力点火時期}

エンシンは最大出力混合比で運転されることが望ましいので あるがこてではまず混合比と最高出力点火時期との関係を求 めた。イソオクタンを然料とし，回転数 $900 \mathrm{rpm}$, 混合気温度

* 昭和 38 年 4 月 10 日受理

** 東京大学航空研究所, Aeronautical Research Institute, The University of Tokyo

*** ゼネラル石油株式会社, General Sekiyu K.K.

***** 日本鉱業株式会社中央試験所, Central Research Laboratory, Nippon Mining Co., Ltd. $50^{\circ} \mathrm{C}$ にわいて各压縮比について 点火時期之出力の関係を調へ た結果が図 1である。との結果から各混合比における最高出力 点火時期を求め混合比と点火時期の関係を示したのが図 2 であ る。一般に混合比が最大出力混合比上りも希薄になるにつれて
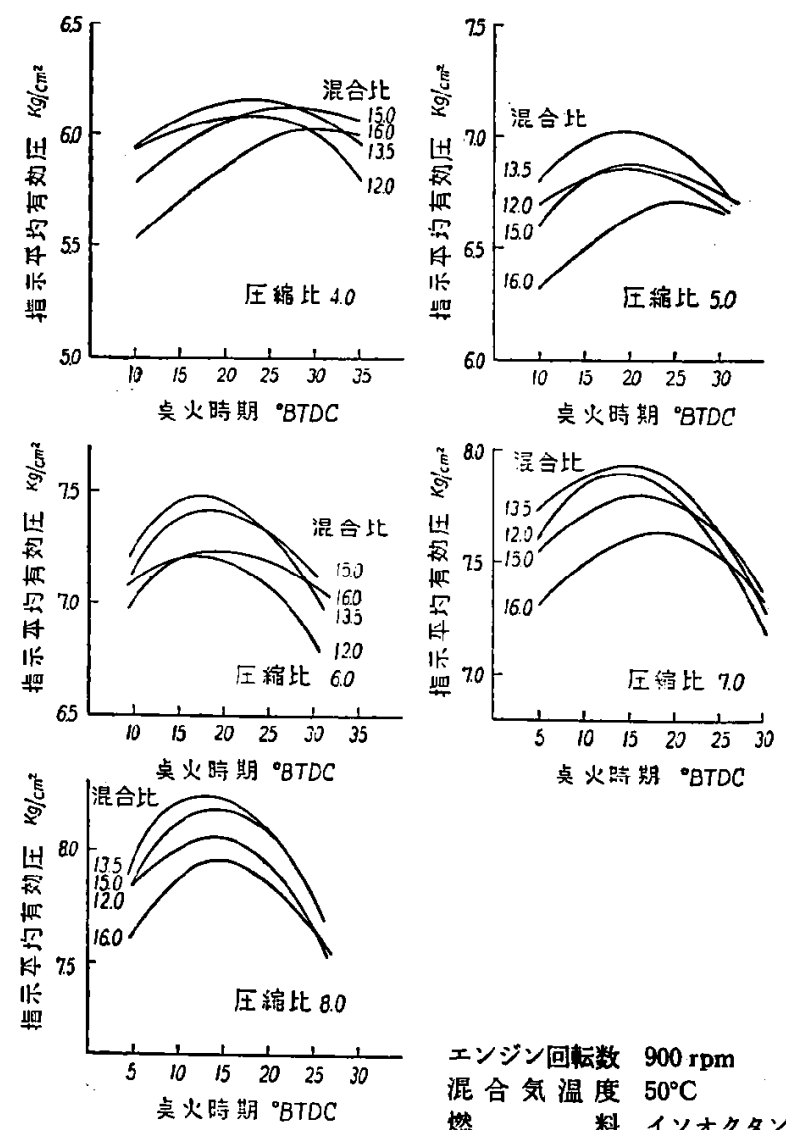

图 1 点火時期と指示平均有奻圧 
最高出力点火時期は進み，低圧 樎比のときはど混合比の影䄷を うけやすい。一定混合比につい ての压縮比之最高出力点火時期 の関保は図 3 に示したとおりで あり., 压档比の高いほど最高出 力点火時期は遅れてくることが 認められる。樶高出力点火時期 が希薄混合比のときには進み， 王綰比が高いときには邁れてく るととは火炎速度がてれをきめ

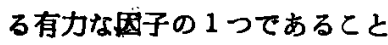
を示している。

2.2 回枟数と服高出力点 火時期

図4は最大出力混合比，混 合気温度 $50^{\circ} \mathrm{C}$ の条件の下で， 回転数 600,900 および 1,200 Ipmについて実験した結果で ある。回転数の高い場合ほど 最高出力点火時期が進み，殴 縮比の影要が大きくなるとと が示されている。

2.3 湿合気温度と报高出 力点火時期

混合気温度の最高出力点火 時期への影帮を求めるために 混合気温度を $150^{\circ} \mathrm{C}$ とし，回 転数 $900 \mathrm{rpm}$, 最大出力混合 比で実酫した。この結果，混 合気温度が高いために充テン 率か低下し出力は小さくなっ ているが，王䈤比と最高出力 点火時期の関係は混合気温度 $50^{\circ} \mathrm{C}$ の結果とほとんど同し

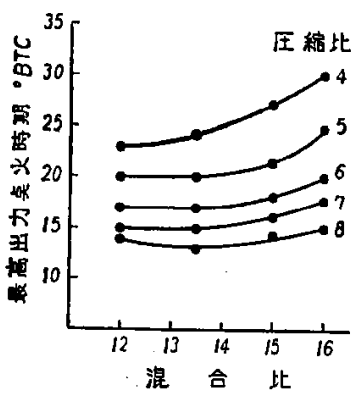

エンジン回轱数 $900 \mathrm{rpm}$ 混合気温度 $50^{\circ} \mathrm{C}$ 図 2 混合比と点火時期

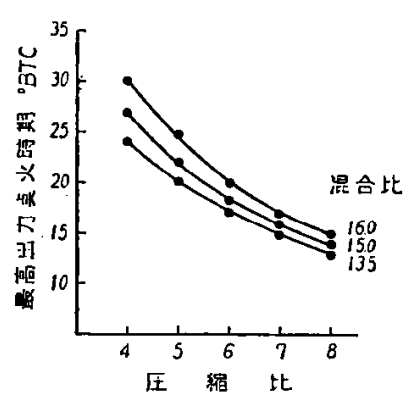

エンジン回伝数 $900 \mathrm{rpm}$ 混合気温度 $50^{\circ} \mathrm{C}$ 図 3 圧樎比々点火時期

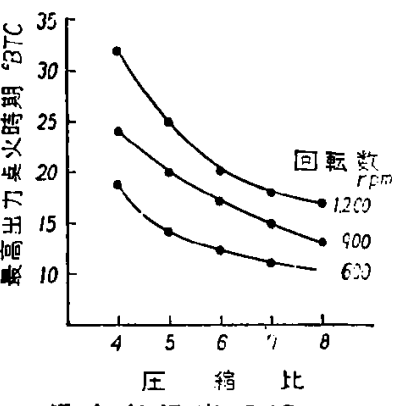

混合気温度 $50^{\circ} \mathrm{C}$ 最大出力混合比

四 4 压耤比と点火時期
㑯向にあるととが認められた。また，改筫ナフサを燃料とした ときの回転数 $900 \mathrm{rpm}$, 混合気温度 $50^{\circ} \mathrm{C}$ における圧縮比と最 高出力点火時期の関係 致した。実際には混合気温度あるいは然料によって火炎速度か 異なり，てれは最高出力点火時期にも影暂すると思われるが， 最高出力点火時期付近ではわずかの点火時期のちがいは出力に あまり影翌しないために测定誤差範囲内で一致するのであろ う。

\section{3 リサーチ法およびモータ法の点火時期}

リサーチ法における点火時期は $13^{\circ} \mathrm{BTDC}$ 一定であり，モー 夕法では自動進角䈉により面縮比が高くなるにつれて痋れ る”。とれらの点火時期が串験で求めた最高出力点火時期とど のような関係にあるか比較してみる。

3.1 リサーチ法の点火時期ट最高出力点火時期

リサーチ法運転条件とこの実験条件では吸入空気温度，湿度 わよひ混合比などにちがいがあるが，図4亿示した回転数 600

$\mathrm{rpm}$ の結果からみると点火特期 $13^{\circ} \mathrm{BTDC}$ は圧縮比 5.5 亿わ ける最高出力点火時期である。点火時期を $13 \pm 0.5^{\circ} \mathrm{BTDC}$ と すれば圧縮比 5.30 5.80 の籁团では最高出力点火時期にある ととになり，との閏で測定されるオクタン価は 50〜70であっ て、リサーチ法の制定された時代には大部分のガソリンのオク タン価かての筃囲にあったと思われる。

\section{2 モータ法の点火時期と最高出力点火時期}

モータ法の圧維比と点火時

期の関係は図 5 の曲線(1)であ り, 回転数 $900 \mathrm{rpm}$, 混合気 温度 $150^{\circ} \mathrm{C}$ にわける圧縮比と 最高出力点火時期の関係は同 図の曲線(2)である。

モータ法運転条件とこの場 合の運転条件との間にも吸入 空気温度, 湿度わよび混合比 などにちがいがあるが，モー 夕法の点火時期は最高出力点

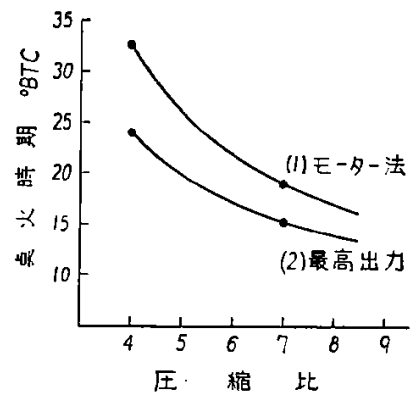

因 5 モーター法の点火時期と 最高出力点火時期 火時期よりもかなり進めてあるてとが明らかである。ノックを 伴う最高出力は実際には意味がないが，標準ノックを生してい るとさの最高出力点火時期之圧縮比の関係は曲楾(2)に近いもの となる゙。また，モータ法の点火時期は最大ノックを示す点火 時期でないととも知られているが2)，てれはモータ法の運転条 件による結果か走行オっタン価と一致するように定められたた めであろう。

\section{4 ノック限界圧維比とオクタン価}

リサーチおよびモータオクタン価は試料が標準ノック強さを 示す圧縮比にわいて，てれをはさむ2つの正標準然料のノック 強さを測定し，内ソウ法によって求められる。したがって圧寉 比とノック強さに基つくくとになるが，本質的には標準ノック を基準とするノック限界代縮比による比較である。本研究の前 報》で報告したように，ての実験は初期ノックを基準とする， ック限界圧縮比で然料のノック性を求めているので，初期ノッ クと標淮ノックによる差異について検討してみるととが必要で ある。

4.1 リサーチ法上の比較

$60 \sim 100$ オクタン価の正標準燃料を用い，回転数 $600 \mathrm{rpm}$, 点火時期 $13^{\circ} \mathrm{BTDC}$, 混合気温度 $50^{\circ} \mathrm{C}$, 混合比 13.5 14.0 ノック限界圧縮比を求め, 乙 れをオクタン価と压縮比の関 係で示すと图 6 の曲線(1)とな る。標準ノック強さで測定す るリサーチオクタン価と压縮 比の関係は同図の曲線(2)とな る。リサーチ法運転条件と実 験条件とでは前述のようなち がいがあるが，初期ノックと 標準ノックによる場合の相互 関係はほほ平行している。初 期ノックの場合には 90 オク タン価の付近が最高出力点火

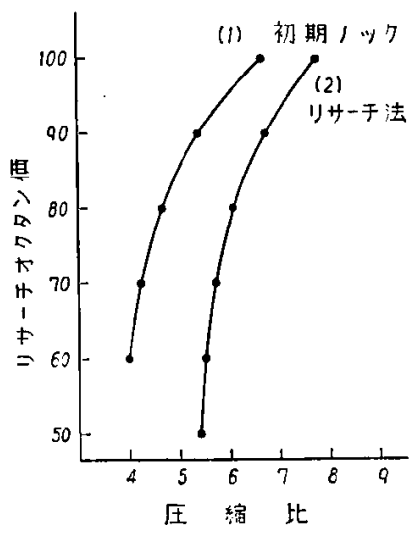

図 6 リサーチオクタン価と圧縮比 
時期で測定されること になる。

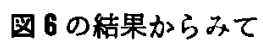
初期ノック限界圧縮比 によってリサーチオク タン価を推定できると とが予想される。前述 の実験条件で改質ナフ サに対する四エチル鉛 の効果を求めると図 1 となるが，ての各試料 のノック限界圧縮比か ら図 6 の曲線(1)を用い てリサーチオクタン価

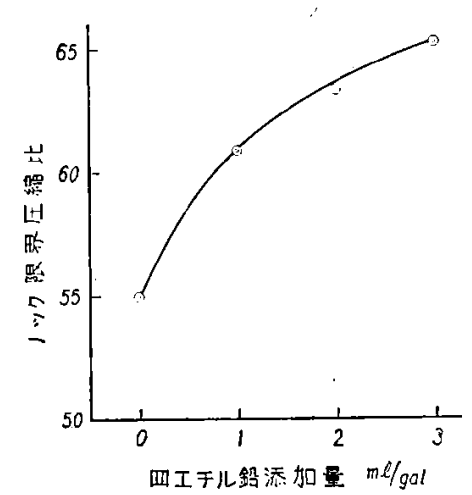

エンジン回転数 $900 \mathrm{rpm}$, 混合気温度 $50^{\circ} \mathrm{C}$ 点火時期 $13^{\circ} \mathrm{BTDC}$, 混合比 14 図 7 四エチル鉛の堵果
を推定すると表 1 となり，かなり近い価が得られる。初期ノッ クによる場合にはそのつど曲線(1)の関係を確かめる必要がある が，一般のオクタン価計測よりは簡単に推定できる。

表 1 ノック限界圧箖比によるリサーチォクタン洒の推定

\begin{tabular}{|c|c|c|c|}
\hline 試 & $\begin{array}{l}\text { 界圧限 } \\
\text { 緶比 }\end{array}$ & $\begin{array}{l}\text { 㨦定才ク } \\
\text { 女価 }\end{array}$ & $\begin{array}{l}\text { リサーチ才 } \\
\text { クタン洒* }\end{array}$ \\
\hline 改 質 & 5.50 & 91.0 & 91.5 \\
\hline 改質ナフサ+TEL $1.0 \mathrm{ml} / \mathrm{gal}$ & 6.09 & 96.0 & 95.5 \\
\hline , TEL $2.0 \mathrm{ml} / \mathrm{gal}$ & 6.33 & 98.0 & 97.7 \\
\hline+ TEL $3.0 \mathrm{ml} / \mathrm{gal}$ & 6.54 & 99.0 & 99.2 \\
\hline
\end{tabular}

* G 社試験空測定值

\section{2 モータ法との比校}

回転数 $900 \mathrm{rpm}$, 混合気温度 $150^{\circ} \mathrm{C}$, 混合比 14 , 自動進角点 火時期にわいて，70〜100 オクタシ価の正標準然料のノック限 界圧縮比を求めた結果が図8の曲線(1)である。モータオクタン

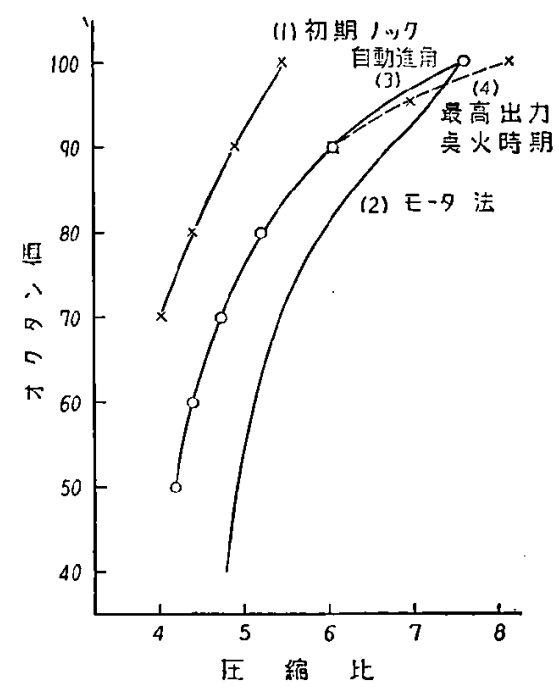

因 8 モータオクタン価と压縮比

価と压縮比の関係は同図の曲線(2)である。この曲線(1)と(2)の関 係は 4.1 の結果とはかなり異なる。すなわち，85 オクタン価 以上になると压縮比の差がしだいに大るくなり初期ノックは標 準ノックの場合と様相の異なるととが示されている。とれは点 火時期が自動進角装置によって定まるために初期ノックにおけ る点火時期が標準ノックの場合よりも進んでおり，その影辢 が現われるからである。図9の実験結果にみられるように60 オクタン価では点火時期 25 30 BTDC の間ではノック限界圧

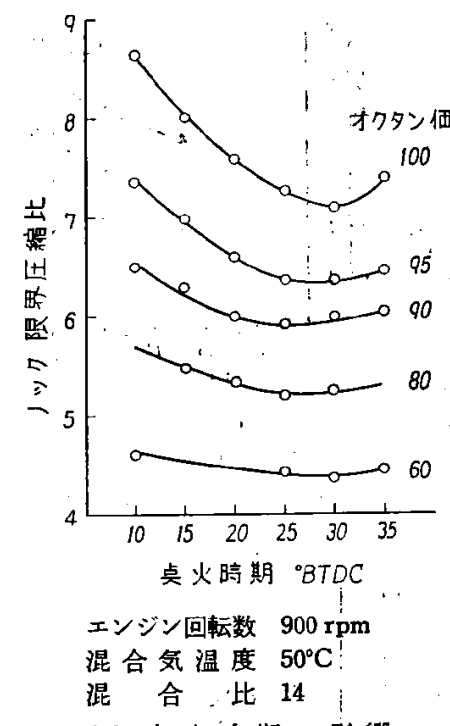

因 9 点火時期の影響 できない。

\section{5 数種の正標準燃料のノック性}

運転条件の然料のノック性への影整は前報》に述べたが，と てではオクタン価の異なる 3 種の正標準然料について点火時期 と混合比のノック性に及ぼす影㗇を求めた。運転条件は回転数 $900 \mathrm{rpm}$, 混合気温度 $50^{\circ} \mathrm{C}$, 点火時期 $10 \sim 35^{\circ} \mathrm{BTDC}$, 混合 比 11〜16, 然料のオクタン価は 60,90 および 100 である。 実験結果を图 10〜12 に示ず。この結果，オクタン価が高くな ると, 点火時期と混合比の影勡がく現われるととが示され た。特に図 12 の 100 オクタン価については希溥混合比で点火 時期の進んでいるときにはノック性が著しく大きくなるとが 認められた。図中のO印は圧縮比，点火時期および混合比が最 高出力位置となる点で，60 オクタン価ではこの位置が運転条 件の中で最もノックを生じやすい最低ノック限界圧縮比の近く にあるが，高オクタン価となるにつれて比較的/ック性の小さ い運転条件へ移る。

图 13〜15 はそれぞれのノック限界圧縮比における軸出力と その圧縮比において最大出力混合比, 最高出力点火時期で得ら れる最高軸出力との割合を出力比として示したしのである。低 オクタン価然料では出力比への運転条件の影辨は小さいが; 高 オクタン価然料では出力比もノック限界圧縮比と同しようにそ の影整が大きくなることがわかる。また，との結果から、1つの 燃料がある环縮比之最高出力点火時期にわいてノックを起す場 合でも，王縮比を高め点火時期を遅らせると出力を低下させる ととなく，しかもノックなしに運転できる場合のあるととが碓 かめられだ。

\section{6 まとめ}

CFR エンシンンの最高出力点火時期をいろいろの压縮比, 回 転数わよび混合比について求め,リサーチ法わよびモータ法の 点火時期と此較した。これによりリサーチ法の点火時期はある 筑困の压縮比では最高出力点火時期之考えてよいか，モー夕法 の点火時期は特に最高出力点火時期と関係のないととが明らか になった。 

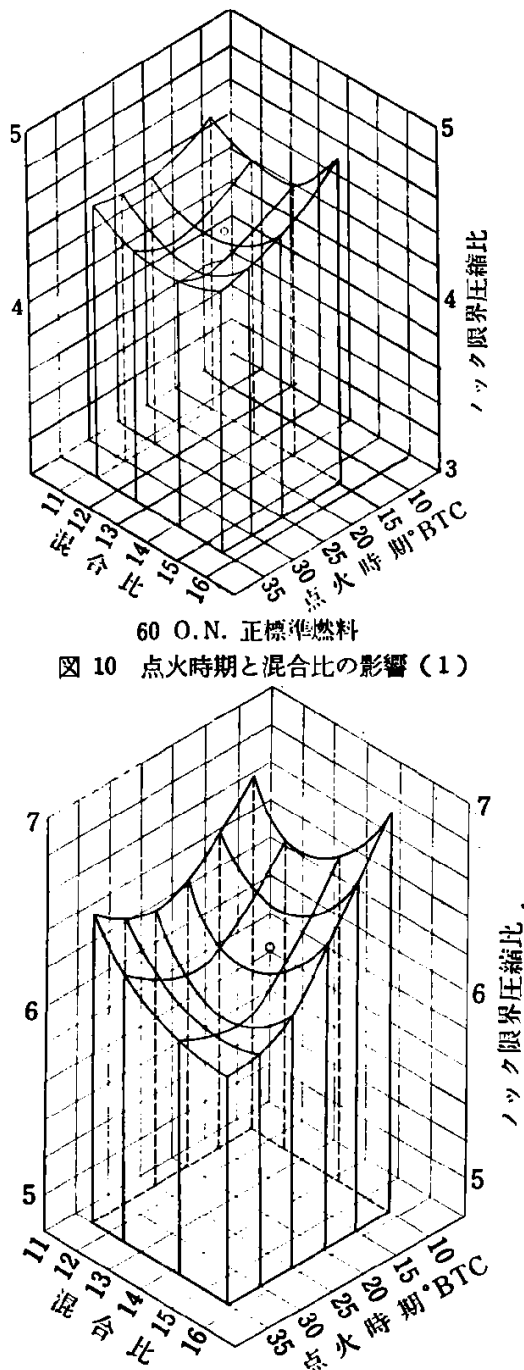

90 O.N. 正標潐燃料

图 11 点火時期と混合比の影響 (2)

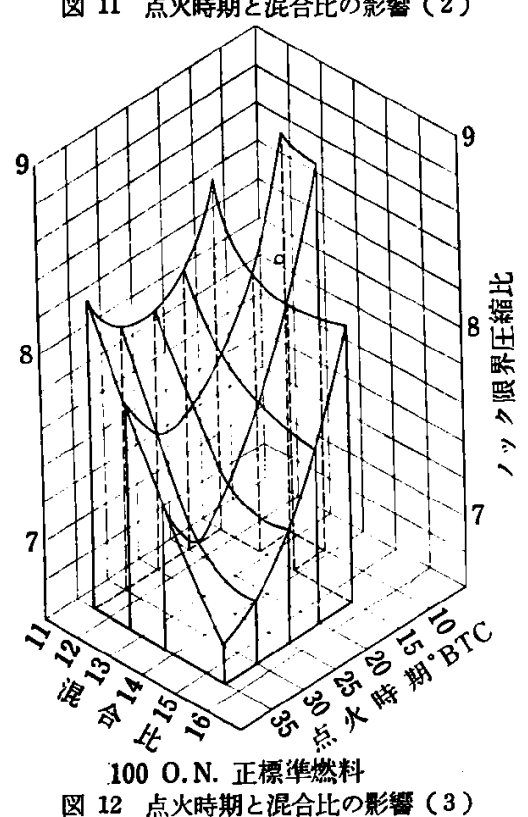

因 12 点火時期と混合比の影䉒 ( 3 )

正標準然料により初期ノックと標準ノックを比較した結果,

ノック限界圧縮比からリサーチオクタン価を推定できることか

示された。またオクタン価の異なる数種の正標準然料について

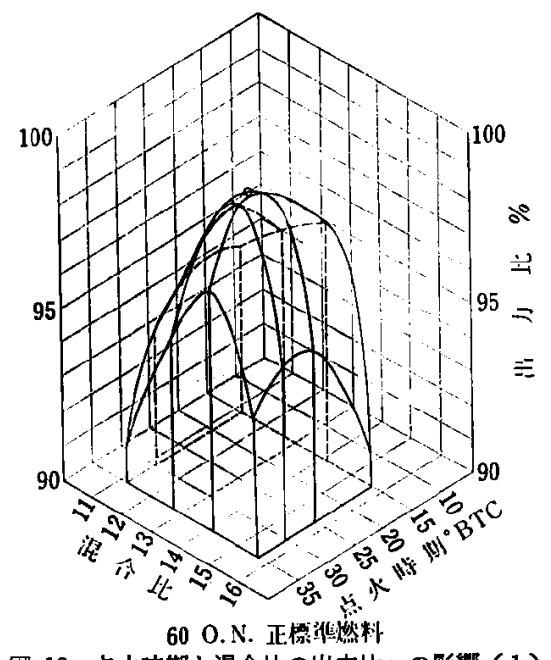

図 13 点火時期と混合比の出力比一の欩望 (1)

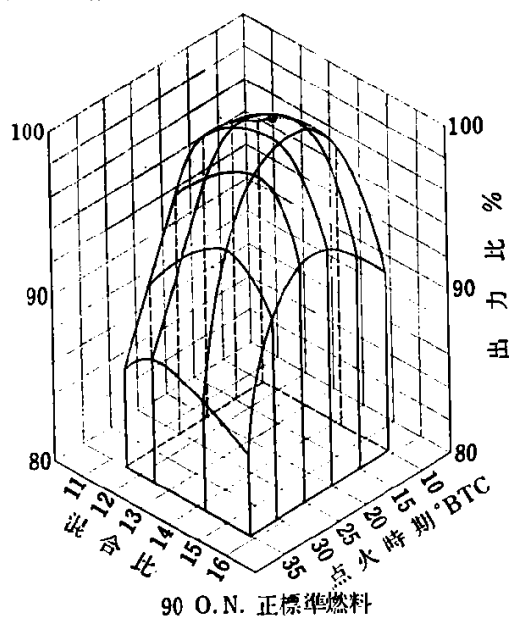

図 14 点火時期と混合比の出力比への影绐 (2)

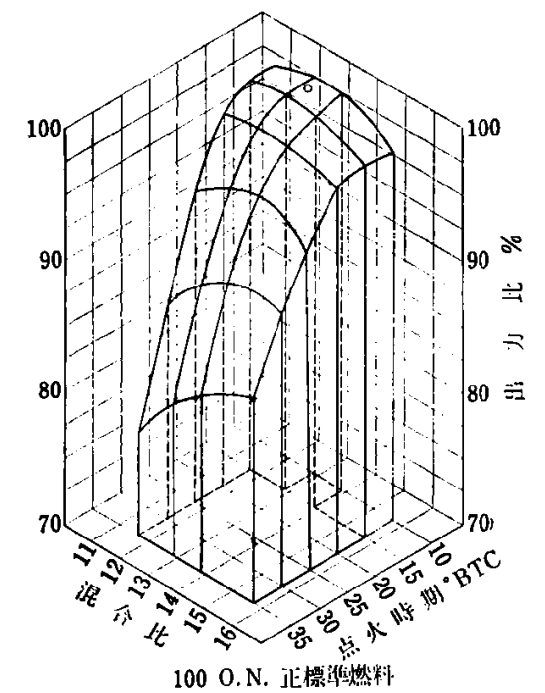

困 15 点火時期と混合比の出力比一の影经 (3)

点火時期之混合比のノック性へ及ぼす影製を求めた結果，オク タン価の高くなるほどその影慗が大きく現われることが示され た。

1) “ASTM Manual for Rating Motor Fuels by Motor and Research Method", (1960).

2) Becker, A.E SAE J. (Trans.) 42,63 (1938)

3) 山崎, 森, 前田, 高取, 石油誌, 6, (8), 595 (1963).

4) Davis, J.D., P.I.M.E. (Auto. Division), 100 (1951-1952). 